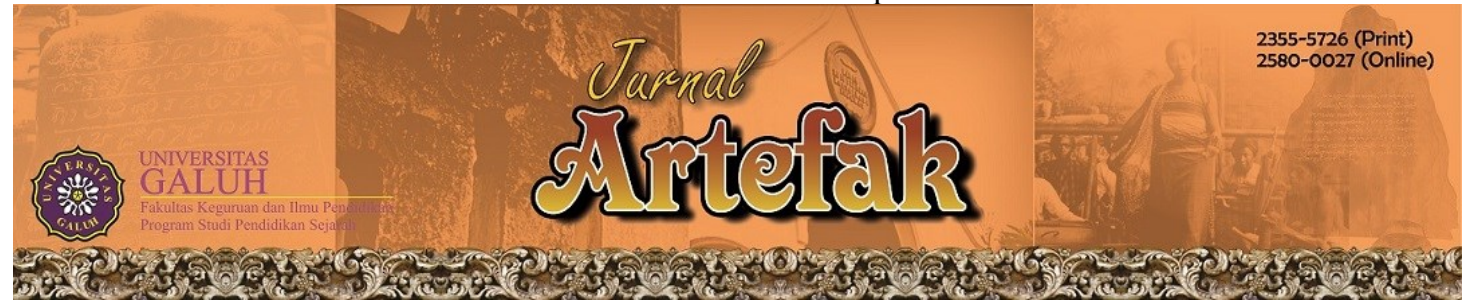

https://jurnal.unigal.ac.id/index.php/artefak/article/view/4669

\title{
UPAYA PBB DALAM MENYELESAIKAN KONFLIK IRAK DAN KUWAIT PADA PERANG TELUK 1990-1991
}

Tri Rahayu Nugraheni

Universitas Negeri Malang, Indonesia

E-mail: trirahayunugraheni3@gmail.com

Sejarah Artikel: Diterima 1-Maret-2021 Disetujui 15-Maret-2021 Dipublikasikan -April-2021

\begin{abstract}
Abstrak
Kajian ini bertujuan untuk membahas mengenai konflik Irak dan Kuwait dalam Perang Teluk 1990-1991 dengan menjelaskan bagaimana konflik Irak dan Kuwait dalam Perang Teluk 1990-1991 bisa terjadi serta menjelaskan bagaimana upaya PBB dalam menyelesikan invasi Irak terhadap Kuwait. Metode yang digunakan adalah metode kajian pustaka menggunakan sumber referensi dari buku dan jurnal terkait konfik Irak dan Kuwait dalam Perang Teluk 1990-1991. Hasil kajian menunjukkan bahwa ada beberapa sebab yang melatarbelakangi invasi Irak terhadap Kuwait diantaranya faktor sejarah, faktor ekonomi, ambisi Saddam Hussein, serta adanya keinginan Irak untuk memperbaiki kondisi perekonomian di negaranya. Selain itu PBB sebagai penjaga keamanan dan perdamaian dunia juga turut berperan penting dalam penyelesaian konflik Irak dan Kuwait.
\end{abstract}

Kata Kunci: Konflik, Irak, Kuwait, Perserikatan Bangsa-Bangsa

This study aims to discuss the Iraq and Kuwait conflicts in the 1990-1991 Gulf War by explaining how the Iraq and Kuwait conflicts in the 1990-1991 Gulf War occurred and explaining how the United Nations efforts to resolve the Iraqi invasion of Kuwait. The method used is the literature review method using reference sources from books and journals related to the Iraq and Kuwait conflicts in the 1990-1991 Gulf War. The results of the study show that there are several reasons behind the Iraqi invasion of Kuwait including historical factors, economic factors, Saddam Hussein's ambition, and Iraq's desire to improve economic conditions in his country. In addition, the UN as the guardian of world security and peace also plays an important role in resolving the Iraq and Kuwait conflicts.

Keyword: Conflict, Iraq, Kuwait, United Nations

\section{PENDAHULUAN}

Konfik menjadi hal yang tak dapat dihindari dalam kehidupan berbangsa dan bernegara. Dalam kehidupan bernegara apalagi ketika kita menjalin interaksi dengan negara lain tentunya akan menjumpai kesalahpahaman ataupun ketidakselarasan antar negara yang kemudian menjadi pemicu konflik. Seperti halnya konflik antar negara Irak dan Kuwait. Konflik Irak dan Kuwait dalam Perang Teluk 1990-1991 tidak terjadi dengan begitu saja. Ada sebab khusus yang kemudian mendasari terjadinya serangan yang dilakukan oleh Irak ke Kuwait.

Penyebab yang mendasari konflik antara kedua negara tersebut terbagi menjadi beberapa faktor. Pertama yaitu adanya faktor sejarah, dulunya Kuwait merupakan bagian wilayah Irak. Kedua yaitu faktor ekonomi, Irak membutuhkan banyak dana untuk memperbaiki kondisi perekonomiannya. Ketiga yaitu adanya Ambisi Saddam Hussein sebagai pemimpin Irak yang ingin menambah 
wilayah kekuasaannya. Keempat yaitu adanya keinginan Irak untuk menguasai ladang minyak yang tentunya untuk menambah perekonomian di negaranya.

Serangan yang dilakukan Irak secara mendadak memicu respon negara lain dan juga PBB yang mempunyai tujuan untuk keamanan dan perdamaian global. Respon dari negara lain muncul utamanya dari negaranegara yang menjalin kerjasama dengan Kuwait. Negara-negara tersebut takut jika Kuwait berhasil diduduki oleh Irak maka kepentingan dari negara mereka bisa terganggu (Latifah \& Ghozali, 2019). Selain itu adanya serangan yang dilakukan oleh Irak membuat Kuwait kehilangan kedaulatannya.

PBB (Perserikatan Bangsa-Bangsa) akhirnya juga turut melakukan penyelesaian terhadap konflik yang sedang terjadi antar Irak dan Kuwait.PBB berusaha mengupayakan adanya keamanan dan perdamaian dunia salah satunya dengan mengeluarkan instruksinya. Instruksi PBB tertuang melalui banyaknya resolusi yang dikeluarkan PBB. Banyaknya resolusi PBB sebagai bukti keseriusan PBB dalam penyelesaian konflik Irak dan Kuwait.

Meskipun disatu sisi pasukan gabungan dari Amerika dan koalisinya terus melakukan penyerangan kepada Irak. Sebelum adanya invasi Irak ke Kuwait juga telah diadakan perundingan antar kedua negara tetapi perundingan tersebut tidak bisa menyelesaikan konflik Irak dan Kuwait. Apa yang dilakukan oleh PBB sebenarnya merupakan bentuk simpati untuk membebaskan Irak dari Kuwait.

Invasi Irak terus saja dilakukan terhadap Kuwait. Upaya perdamaian pun sudah berkali-kali ditawarkarkan oleh PBB. Dewan Keamanan PBB bahkan terus berusaha mengeluarkan resolusi kepada Irak untuk segera meninggalkan Kuwait sebelum dilakukan tindakan militer terhadap Irak. Irak tetap tidak gentar akan resolusi-resolusi yang diberikan PBB. Dengan demikian, penulis tertarik membahas lebih dalam mengenai bagaimana konflik Irak dan Kuwait dalam
Perang Teluk 1990-1991 bisa terjadi dan bagaimana upaya PBB dalam menyelesaikan konflik Irak dan Kuwait dalam Perang Teluk 1990-1991.

\section{METODE PENELITIAN}

Metode penelitian yang digunakan dalam menyusun artikel ini adalah metode kajian pustaka, metode kajian pustaka menggunakan sumber referensi dari buku dan jurnal (Setyosari, 2007). Sumber referensi yang dijadikan acuan dalam kajian teori ini memiliki arti penting dalam mempertimbangkan artikel ilmiah yang sedang dikerjakan. Artikel ilmiah yang didasarkan pada bukubuku dan jurnal-jurnal yang ditemukan nantinya akan diolah kembali sebagai dasar penulisan artikel. Selain itu studi pustaka juga dapat didefinisikan sebagai tekhnik pengumpulan data dengan menelaah buku, literatur, catatan maupun berbagai laporan yang berkaitan dengan masalah yang akan dipecahkan (Nazir, 1988). Dari kedua pendapat tersebut dapat disimpulkan bahwa metode penelitian dengan menggunakan kajian pustaka yaitu merupakan metode penelitian yang didasarkan pada buku, jurnal, literatur maupun catatan dari laporan yang kemudian ditelaah dan kemudian hasil telaah tersebut dapat digunakan untuk memecahkan masalah yang sedang dibahas diartikel yang dikerjakan.

\section{HASIL PENELITIAN DAN PEMBAHASAN}

\section{Konflik Irak dan Kuwait dalam Perang Teluk 1990-1991}

Kuwait adalah sebuah negara yang tergolong kecil di area Teluk. Walaupun menjadi negara yang tergolong kecil di area Teluk tetapi menyimpan sumber daya alam yang luar biasa. Sumber daya alam yang luar biasa itu adalah minyak. Kuwait memiliki 
wilayah yang kaya akan minyaknya. Sedangkan minyak adalah komoditi utama Timur Tengah. Minyak sangat diperlukan sebagai bahan bakar dan juga memegang peranan penting pada periode industri waktu itu (Indriana, 2017).

Minyak tentunya bukan hanya memiliki fungsi yang begitu penting di negaranya tetapi juga memiliki fungsi penting bagi negara lain. Selain itu sistem eksploitasinya minyak di Kuwait cukup memuaskan apalagi dengan biaya yang murah. Itulah akhirnya produksi minyak di Timur Tengah salah satunya di Kuwait meningkat. Negara-negara adidaya dan juga negara lain sangat bergantung terhadap pasokan minyak dari Kuwait.

Cadangan minyak di Kuwaitt juga tergolong sangat banyak. Itulah juga menyebabkan konflik Irak dan Kuwait. Irak tergolong sebagai wilayahnya luas yang bisa saja menyerang Kuwait dengan wilayah yang sempit. Selain ingin menjadikan Kuwait sebagai negara kekuasaannya tujuan invasi Irak ke Kuwait yaitu umtuk menambah luas wilayahnya, ingin memiliki pulau-pulau di Kuwait yang memiliki banyak potensi. Irak juga memiliki tujuan lain yaitu untuk mengontrol harga minyak dipasaran.

Konflik permasalahan bermula dari Kuwait yang dianggap Irak telah mencuri minyak Irak. Selain itu akibat dari Kuwait harga minyak dunia dipasaran menjadi turun. Sementara dari pihak Kuwait menuduh Irak telah meninggalkan kewajibannya terhadap pembayaran utang ke Kuwait. Akibatnya dtimbullah invasi yang dilakukan Irak terhadap Kuwait. Irak bahkan beranggapan bahwa Kuwait merupakan bagian dari wilayahnya.

Invasi yang dilakukan oleh Irak ke Kuwait tidak terjadi jika tanpa disertai sebab yang mendasarinya. Penyebab yang mendasari invasi Irak ke Kuwait disederhanakan menjadi 4 faktor yang kemudian menjadi faktor pendorong Irak dalam aksinya menyerang dan menguasai Kuwait. Penyebab invasi Irak terhadap Kuwait diantaranya yaitu dari faktor sejarah, faktor ekonomi, ambisi Saddam Hussein sebagai pemimpin Irak, serta adanya Irak untuk menguasai ladang minyak (Solichien, 2014: 87-89).

Faktor sejarah Irak dan Kuwait yaitu adanya permasalahan yang ternyata sudah berlangsung cukup lama. Permasalahannya yaitu Irak ingin Kuwait menjadi bagian dari negara Irak. Keinginan Irak menjadikan Kuwait bagian dari negaranya dikarenakan Kuwait dulunya memang bagian dari wilayah Irak karena berasal dari daerah kekuasaan Ottoman. Namun akhirnya terpisah akibat kolonialis Inggris. Sikap campur tangan Inggris ini bukan tanpa sebab. Inggris ingin melindungi ladang minyak Kuwait yang sewaktu-waktu bisa jatuh ke tangan Irak. Inggris beranggapan bahwa jika ladang minyak itu dikuasai Irak maka harga minyak dunia akan naik (Anggono, 2002). Oleh karena itu Inggris membantu Kuwait ketika menghadapi serangan-serangan dari Irak salah satunya dengan mengirimkan pasukannya ke Kuwait.

Tidak hanya Inggris yang turut membantu Kuwait dalam usahanya untuk terbebas dari Irak. Liga Arab juga turut membantu Inggris dalam usahanya mengusir Irak dari Kuwait. Liga Arab melakukan sidang darurat pada 8 Agustus 1990 dengan hasilnya mendelegasikan pasukan gabungan Arab dengan tujuan untuk mengusir Irak dari Kuwait. Rencana selanjutnya yaitu perundingan yang dilakukan oleh kedua negara tersebut. Liga Arab dan negara-negara lain tentunya tidak ingin Kuwait jatuh digenggaman Irak yang nantinya dapat berakibat terganggunya kepentingan dari negara-negara yang menjalin kerjasama dengan Kuwait.

Faktor ekonomi Irak salah satunya disebabkan adanya kemerosotan ekonomi dan rusaknya infrastruktur Irak akibat perang Irak melawan Iran (Mariyati, 2003). Kemerosotan ekonomi dan infrastruktur mendorong Irak untuk memperbaiki ekonomi dan infrastruktur yang ada di negaranya. Negara Irak pada saat 
itu pemasukannya tergantung pada ladang minyak. Sedangkan pada saat itu harga minyak tergolong rendah di dunia. Rendahnya harga minyak dikarenakan adanya negara pesaing yang juga mempunyai cadangan minyak yang banyak. Salah satunya yaitu Kuwait yang juga terkenal dengan kekayaan minyaknya sehingga membuat harga minyak dunia menjadi rendah.

Rendahnya harga minyak di dunia mendorong Irak untuk meminta bantuan kepada Arab dan Kuwait. Namun kedua negara tersebut tidak merespon baik permintaan Irak. Akhirnya Irak melakukan berbagai upaya untuk mencapai keinginannya salah satunya dengan meminta uang kepada Kuwait dikarenakan Kuwait dituduh Irak telah mencuri minyak di wilayah Irak disertai ancaman dari Irak. Namun Kuwait tetap kukuh terhadap pendiriannya dan tidak mau menuruti tuntutan Irak.

Ambisi Saddam Hussein juga menjadi faktor penyebab penyerangan Irak terhadap Kuwait (Pusat Data dan Analisis Tempo, 2019). Saddam Hussein merupakan pemimpin Irak pada saat itu. Saddam Hussein sangat berambisi menjadi penguasa Arab dan menguasai Kuwait. Ambisi itu mendorong Saddam Hussein untuk memperkuat kekuatan militernya dan juga memperkaya perekonomiannya. Dengan menguasai Kuwait maka bisa menguasai ladang minyaknya yang begitu melimpah. Melimpahnya sumber daya alam berupa minyak membuat Kuwait menjadikan dirinya bisa mengontrol harga minyak bahkan bisa menaikkan harga minyak bagi negara-negara yang membutuhkannya.

Bahkan Irak membantu negara-negara Arab yang mengalami kesusahan untuk menarik simpati negara-negara Arab. Ketika negara-negara Arab bersimpati kepada Irak harapan kedepannya yaitu mereka bisa mendukung Irak menjadi penguasa Arab. Akibat perang Irak melawan Iran membuat perekonomian dan kekuatan militer Irak melemah. Ambisi lain Irak yaitu menguasai Kuwait. Dengan menguasai Kuwait harapan kedepannya yaitu ekspor impor Irak melalui akses laut akan berjalan lancar. Selain itu alasan lain ambisi Irak menguasai Kuwait yaitu karena Kuwait merupakan anggota tetap PBB sehingga akan sangat menguntungkan Irak jika Irak bisa menguasai Kuwait.

Faktor penyebab selanjutnya yaitu Irak ingin menguasai ladang minyak Kuwait (Nurmantyo, 2017). Adanya kepentingan nasional yang tertanam kuat membuat Irak akhirnya bisa menguasai Kuwait selama 24 jam dan menjadikan Kuwait sebagai provinsi bagian negara Irak. Irak juga tidak gentar ketika mendapat kecaman ataupun tekanan dari dunia internasional. Adanya serangan yang dilakukan oleh Amerika dan negaranegara koalisinya juga tidak membuat Irak gentar. Bahkan resolusi dari PBB pun tidak ditanggapi dengan serius.

Irak mencari ide untuk meredam kecaman dan tekanan dunia internasional. Salah satu cara yang Irak lakukan adalah dengan melakukan tawar menawar bahwa Irak akan keluar dari Kuwait jika Israel juga keluar dari Arab. Tawar menawar dilakukan Irak supaya mendapat simpati dari warga Arab. Selain itu Irak juga menyandra pekerja asing sebagai tameng Irak (Sihbudi, 1997). Tindakan Irak justru membuat kemarahan dunia internasional yang akhirnya membuat adanya tindakan militer terhadap Irak.

\section{Upaya PBB dalam Menyelesaikan Konflik Irak dan Kuwait dalam Perang Teluk 1990-1991}

Perang Teluk 1990 disebut juga Gulf War yang disebabkan adanya invasi oleh oleh Irak ke Kuwait . Adanya Invasi yang berupa penyerangan oleh Irak ke Kuwait cukup menarik simpati negara-negara yang menjalin hubungan kerjasama dengan Kuwait. Penyerangan Irak ke Kuwait juga menarik simpati Liga Arab yang kemudian juga turut andil seperti PBB dengan melindungi wilayah Kuwait.

Adanya serangan atau invasi yang dilakukan oleh Irak membuat Kuwait 
kehilangan kedaulatannya. Itulah mengapa akhirnya banyak simpati dari negara-negara internasional yang menjalin hubungan kerjasama dengan Kuwait. Salah satunya yaitu adanya himbauan dari Irak supaya negaranegara yang menjalin hubungan internasional dengan Kuwait harus beralih ke Irak sebab Kuwait sekarang masuk bagian provinsi Irak. Hal tersebut kemudian memicu reaksi dari negara-negara internasional yang menjalin hubungan dengan Kuwait.

Beberapa negara juga menanggapi Invasi Irak terhadap Kuwait diantaranya yaitu Amerika Serikat, Inggris, Prancis, Uni Soviet, China, Jepang, Jerman, Mesir, Arab Saudi, Suriah, Yordania, Yaman, Kuba, Palestina, dan Indonesia (Solichien, 2014). Reaksi yang ditimbulkan dari negara-negara di dunia yaitu ada yang mendukung Invasi Irak terhadap Kuwait dan ada pula yang mengecam Invasi Irak terhadap Kuwait.

Amerika beserta negara-negara lain kemudian tergugah untuk membantu Kuwait dikarenakan mereka takut apa yang dilakukan Irak terhadap Kuwait dapat berpengaruh terhadap negara mereka salah satunya mengenai pasokan minyak dari Kuwait. Selain itu negara lain seperti Arab juga mengecam tindakan Irak dalam upayanya untuk menguasai Kuwait Negara-negara maju serta negara-negara lain yang mendapat pasokan minyak dari Kuwait juga takut ketika Kuwait berhasil dikuasai Irak maka harga minyak bisa saja menjadi tinggi (Annisa, Setiyono, \& Supriyadhie, 2019).

Amerika akhirnya turut bergerak untuk menyelesaikan dikarenakan Amerika Serikat merasa bahwa penyerang itu dapat mengancam kepentingan di negaranya mengingat pentingnya Kuwait sebagai pemasok minyak untuk Amerika. Amerika Serikat juga berusaha melakukan berbagai cara untuk membebaskan Kuwait dari Irak salah satunya dengan meminta bantuan kepada PBB untuk memberikan resolusi konflik Irak dan Kuwait.
Amerika tidak bergerak sendirian dalam menyelesaikan konflik antara Irak dan Kuwait. Amerika memanfaatkan PBB untuk menjadi pelindung tindakan Irak untuk melakukan penyerangan terhadap Irak. PBB melalui Dewan Keamanannya berusaha memyelesaikan konflik dengan jalan perumdingan tetapi nampaknya apa yang dilakukan PBB sia-sia.

Amerika beranggapan bahwa apa yang dilakukan oleh Irak ke Kuwait merupakan bentuk pelanggaran hak asasi manusia. Berdasar apa yang disampaikan Amerika akhirnya Dewan Keamanan PBB memberlakukan sanksi bagi Irak. Selain sanksi, PBB juga turut menyetujui dibentuknya koalisi Amerika dan negaranegara lain dalam upayanya membebaskan Kuwait dari Irak. Upaya lain yang dilakukan PBB yaitu dengan melumpuhkan ekonomi Irak serta tidak menyetujui adanya penggunaan senjata militer oleh Irak ke Kuwait.

PBB sepakat dengan anggapan Amerika bahwa penyerangan Irak terhadap Kuwait merupakan salah satu wujud pelanggaran terhadap hak asasi manusia. PBB mengecam aksi Irak yang menduduki Kuwait. PBB juga tidak mengakui bahwa Kuwait masuk bagian provinsi Irak. PBB berusaha mengeluarkan instruksinya terbukti dengan banyaknya resolusi yang dikeluarkan PBB walaupun akhirnya tidak mampu membuat Irak pergi meninggalkan Kuwait (Anggono, 2002).

Berbagai reolusi yang diterbitkan isinya diantaranya yaitu sanksi ekonomi kepada Irak, penyetujuan adanya tindakan penyerangan koalisi Amerika Serikat dan negara koalisinya kepada Irak, serta adanya pengaturan mengenai kekuatan militer.PBB sebagai penjaga keamanan dan perdamaian dunia juga turut memegang peranan penting dalam invasi Irak terhadap Kuwait yang menandakan keseriusan PBB dalam menyelesaikan konflik Irak dan Kuwait.

PBB cukup berperan banyak dalam penyelesaian invasi Irak terhadap Kuwait. 
PBB akhirnya turut melakukan penyelesaian invasi karena PBB beranggapan bahwa invasi yang dilakukan Irak terhadap Kuwait merupakan bentuk pelanggaran. Oleh karena itu PBB mencoba melakukan upaya perdamaian dengan mengirimkan resolusi damai kepada Irak untuk segera meninggalkan wilayah Kuwait dan berhenti melakukan invasi terhadap Kuwait.

Tahun 1990, tepatnya dibulan Agustus tanggal 2 Irak telah menduduki Kuwait setelah melakukan invasi ke Kuwait (Indriana, 2017). Sesaat setelah itu PBB mengadakan rapat yang mempertemukan negara anggota $\mathrm{PBB}$ guna membahas mengenai invasi Irak terhadap Kuwait. Hasil rapat yang diselenggarakan PBB akhirnya memutuskan untuk mengeluarkan resolusi 660 yang isinya meminta Irak untuk segera menarik mundur pasukannya. Dalam hal ini juga diberlakukan tanpa syarat bagi Irak untuk meninggalkan Kuwait. Namun resolusi PBB tersebut tidak dilaksanakan oleh Irak (Mariyati, 2003). Irak masih saja teguh dengan pendiriannya untuk menguasai Kuwait.

Tahun 1990, tepatnya bulan Agustus tanggal 6 PBB melalui Dewan Keamanannya menginstrusikan kepada Irak melalui resolusi 661 yang isinya berupa sanksi ekonomi kepada Irak. Tetapi PBB tetap membiarkan adanya bantuan kesehatan dan juga pangan bagi rakyat Irak (Adolf, 2020). Embargo yang diberikan oleh PBB dimaksudkan untuk membuat Irak kesulitan untuk memasok kebutuhan perang.

Adanya sanksi ekonomi yang diberikan oleh PBB kepada Irak diharapan kedepannya bisa menghentikan invasi yang dilakukan Irak terhadap Kuwait. Harapan tersebut dikuatkan dengan melemahnya perekonomian Irak ketika sanksi ekonomi dari PBB dilaksanakan. Namun, embargo yang diberikan PBB nampaknya tidak berpengaruh terhadap pendirian Irak. Irak tetap saja tidak mau mematuhi resolusi PBB sehingga Irak terus melakukan invasi terhadap Kuwait.
Resolusi 661 nampaknya tidak membuat Irak untuk segera meninggalkan Kuwait. Akhirnya Dewan kemanan PBB kembali mengeluarkan resolusi. Resolusi yang dikeluarkan Dewan Keamanan PBB yaitu resolusi 662. Resolusi 662 isinya berupa penegasan kembali supaya Irak segera meninggalkan Kuwait (Mariyati, 2003). Adanya resolusi 662 Dewan keamanan PBB menjadi bukti upaya penyelesaian penyerangan Irak ke Kuwait secara damai. PBB masih menjalankan tujuannya untuk turut serta menjaga keamanan dan perdamaian dunia.

Konflik Irak dan Kuwait akan membawa dampak bagi sekitarnya. Salah satunya bagi para warga negara asing yang di Irak maupun di Kuwait. Warga negara asing bisa saja dijadikan tameng oleh Irak untuk berlindung. Akhirnya PBB melalui Dewan Keamanannya juga menerbitkan resolusi 664 yang didalamnya menginstrusikan Irak harus melindungi orang asing baik yang ada di Irak maupun di Kuwait.

Resolusi PBB 664 dimaksudkan untuk melindungi warga negara asing dari dampak yang timbul akibat invasi Irak terhadap Kuwait. PBB selain memberikan bantuan kesehatan dan juga pangan bagi Irak juga memberikan keamanan tentunya bagi negara asing yang berada di wilayah Irak ataupun Kuwait. Warga negara asing perlu mendapat perlindungan dikarenakan konflik Irak dan Kuwait sedang gencarnya dilakukan sehingga ditakutkan bisa memakan korban jiwa tak terkecuali bagi mereka warga negara asing yang tidak mengetahui mengenai konflik yang ada.

Tahun 1990, tepatnya dibulan Agustus tanggal 25 PBB melalui Dewan Keamanannya menerbitkan resolusi 665 yang isinya berupa adanya tindakan sepadan yang dilakukan dalam situasi tertentu aga Irak mematuhi resolusi PBB. Selain itu dalam resolusi 665 juga mengadakan pembentukan komite sanksi khusus untuk memantau embargo oleh negaranegara anggota PBB terhadap Irak. Tujuan 
dicetuskannya sanksi tersebut yaitu untuk melemahkan Irak. Ketika Irak melemah maka Irak akan meninggalkan Kuwait. Namun, hal tersebut nampaknya juga tidak dilaksanakan oleh Irak. Irak masih saja kukuh akan pendiriannya yaitu menginvasi Kuwait.

PBB melalui Dewan Keamanannya juga menerbitkan resolusi 666 yang menyatakan bahwa Irak harus menghormati konvensi Jenewa. Resolusi ini dikeluarkan karena Irak melakukan pelanggaran terhadap hak asasi manusia pada warga Kuwait yang dilakukan oleh tentara-tentara Irak. Resolusi ini dikeluarkan oleh Dewan Keamanan PBB untuk melindungi hak-hak asasi warga Kuwait yang terkena imbas dari adanya invasi Irak terhadap Kuwait.

Dalam penyelesaian invasi Irak dan Kuwait PBB tidak hanya mengeluarkan resolusi damai. Tetapi PBB juga mengadakan diplomasi internasional yang dihadiri oleh Sekjen PBB dan juga wakil perdana mentri Irak di Yordania pada 31 Agustus 1990 (Solichien, 2014). Dalam diplomasi tersebut PBB menduga Irak dapat melaksanakan resolusi yang diinstrusikan. Dalam diplomasi kali ini sekjen PBB juga menegaskan akan adanya penggunaan militer jika mendapat persetujuan anggota-anggota PBB. Namun upaya yang dilakukan oleh PBB tidak ditanggapi serius oleh Irak. Irak bahkan tidak melaksanakan resolusi PBB.

Pada tanggal 13 september 1990 Dewan Keamanan PBB kembali mengeluarkan resolusi 666. Resolusi 666 isinya mengenai pemberian hak kepada komite sanksi nasional. Hak yang diberikan yaitu untuk memantau pasokan perlengkapan kesehatan warga Irak maupun pasokan pangan bagi rakyat Irak masih terus terpenuhi atau tidak. Pemantauan kebutuhan manusia di Irak dilakukan oleh PBB atas dasar kemanusian. Irak memang telah melakukan pelanggaran atas tindakannya menginvasi Kuwait, tetapi rakyat Irak juga perlu adanya bantuan kemanusiaan karena rakyat Irak juga menjadi korban dalam penyerangan Irak ke Kuwait.
PBB melalui Dewan Keamanannya kembali menerbitkan resolusi 667 yang isinya menyatakan bentuk kecaman yang ditujukan kepada Irak atas aksi irak mengubah pengaturan kependudukan warga Kuwait serta menghanguskan catatan resmi yang selama ini dijaga oleh Kuwait (Mariyati, 2003). Resolusi 667 dikeluarkan oleh Dewan Keamanan PBB karena tindakan yang dilakukan Irak sudah diluar batas. Sehingga resolusi 667 dikeluarkan untuk mengecam tindakan Irak terhadap Kuwait.

Beberapa upaya damai telah dilakukan oleh PBB dalam melerai konflik Irak ke Kuwait. Namun dari banyaknya resolusi yang dikeluarkan PBB tidak satupun ada yang dilaksanakan oleh Irak. Akhirnya Dewan Keamanan PBB mengeluarkan resolusi 678 pada 29 November 1990 yang isinya berupa mandat yang ditujukan kepada anggota PBB untuk melakukan segala cara dalam usahanya mengusir Irak dari Kuwait (Anggono, 2002). Rentan waktu yang diberikan kepada Irak untuk keluar dari Kuwait yaitu sampai tanggal 15 Januari 1991. Apabila dalam kurun waktu yang diberikan Irak belum juga meninggalkan Kuwait maka tindakan itu dianggap sebagai pelanggaran nyata terhadap Dewan Keamanan PBB.

Resolusi 678 merupakan resolusi yang dikeluarkan oleh Dewan Keamanan PBB atas kerjasamanya dengan Amerika Serikat. Kerjasama ini muncul dikarenakan resolusi yang dikeluarkan Dewan Keamanan PBB tidak akan berpengaruh tanpa adanya pelaksanaan. Oleh karena itu Amerika Serikat membantu PBB menghimpun koalisi internasional dalam usahanya untuk mengusir Irak jadi Kuwait (Cleveland, 1995). Terbentuknya koalisi internasional dimaksudkan untuk melibatkan pasukan militer negara-negara anggota PBB dalam upaya militer PBB sebagai bentuk pelaksanaan resolusi 678. Dengan adanya koalisi internasional yang tergabung dalam militer PBB harapan kedepannya yaitu bisa menyelesaikan konflik antara Irak dan Kuwait 
dalam Perang Teluk 1990-1991 (Pusat Data dan Analisis Tempo, 2019).

Operasi Badai Gurun akhirnya dilakukan karena hingga tanggal 15 Januari 1991 Irak tidak juga meninggalkan Kuwait (Anggono, 2002). Operasi Badai gurun dilakukan oleh pasukan multinasional pada 17 Januari 1991 yang melibatkan perang darat, laut, dan udara (Mariyati, 2003). Walaupun sudah terdesak oleh pasukan multinasional Irak tidak kunjung mundur. Akhirnya pada 28 Februari 1991 Saddam Hussein memerintahkan pasukan Irak untuk kembali ke posisi awal sebelum memasuki wilayah Kuwait.

Walaupun diserang oleh Amerika Serikat dan juga negara koalisinya yang cukup kuat tetap tidak bisa membuat Irak gentar. Justru Irak tetap bertahan dan kukuh tidak ingin meninggalkan Kuwait. Bahkan Irak menggunakan startegi yang menyatakan ia akan mundur ketika Israel mundur dari Palestina.

Sebelum dilakukan penyerangan, diplomasi dilakukan terlebih dahulu dengan tujuan supaya Irak mau kembali ke negaranya dan tidak melakukan penyerangan lagi kepada Kuwait. Upaya meminta Irak supaya meninggalkan Kuwait nampak sia-sia dikarenakan Irak tetap kukuh tidak mau meninggalkan Kuwait. Penolakan yang dilakukan Irak akhirnya membuat Amerika dan negara koalisinya melakukan serangan kepada Irak. Upaya penyerangan Amerika dan negara koalisi itu biasa disebut Operasi Badai Gurun. Adanya Operasi Badai Gurun membuat Irak akhirnya menyetujui untuk meninggalkan Kuwait. Dengan demikian konflik Irak dan Kuwait dalam Perang Teluk 1990 telah dapat diselesaikan dengan baik (Winarno, 2014).

Berbagai upaya perdamaian terus diusahakan dalam usaha menyelesaikan konflik Irak dan Kuwait salah satunya oleh PBB. Meskipun disatu sisi pasukan gabungan dari Amerika dan koalisinya terus melakukan penyerangan kepada Irak. Penyerangan gabungan tersebut dilakukan karena Irak tidak kunjung meninggalkan Kuwait. Sebelum adanya invasi Irak ke Kuwait juga telah diadakan perundingan antar kedua negara tetapi perundingan tersebut tidak bisa menyelesaikan konflik Irak dan Kuwait. Apa yang dilakukan oleh PBB sebenarnya merupakan bentuk simpati untuk membebaskan Irak dari Kuwait.

Salah satu upaya PBB yang cukup penting yaitu melakukan upaya untuk membebaskan Kuwait dari Irak salah satunya yaitu embargo kepada Irak. Secara tidak langsung membuat Irak melemah. Embargo ekonomi pada 1990 sebagai hukuman diberlakukan karena Irak melakukan invasi ke Kuwait Selain itu.

\section{KESIMPULAN}

Konflik Irak dan Kuwait dalam Perang Teluk 1990-1991 terjadi dikarenakan adanya beberapa sebab yang mempeloporinya. Sebab yang mempeloporinya terbagi menjadi beberapa faktor penyebab. Pertama yaitu didasarkan akan adanya adanya faktor sejarah dimana Kuwait dulunya merupakan bagian wilayah Irak. Kedua yaitu faktor ekonomi, Irak membutuhkan banyak dana untuk memperbaiki kondisi perekonomiannya yang nyaris hancur akibat peperangan yang dilakukan sebelumnya. Ketiga yaitu adanya Ambisi Saddam Hussein sebagai pemimpin Irak yang ingin menambah wilayah kekuasaannya. Saddam Hussein berniat menguasai sumber daya alam yang berada di Kuwait salah satunya yaitu minyak. Keempat yaitu adanya keinginan Irak untuk menguasai ladang minyak yang tentunya untuk menambah perekonomian di negaranya. Dikuasainya Kuwait oleh Irak bisa membuat Irak menjadi negara pemasok minyak bagi negara-negara lain selain itu Irak juga bisa mengontrol harga minyak dipasaran.

Terkait aksi Irak yang melakukan penyerangan kepada Kuwait menimbulkan 
respon dari beberapa negara. Beberapa negara diantaranya yaitu negara-negara yang terlibat kerjasama dengan Kuwait. Tentunya kerjasama dalam pemasokan minyak karena Kuwait merupakan negara penghasil minyak. Beberapa negara yang menjalin kerjasama dengan Kuwait menolak tegas tindakan Irak yang menduduki Kuwait. Negara-negara tersebut akhirnya bergabung bersama koalisi Amerika dengan maksud untuk membebaskan Kuwait dari tangan Irak.

Respon juga ditujukan oleh PBB yang memiliki tujuan untuk menjaga keamanan dan perdamaian dunia. Dalam menjalankan tujuannya PBB juga turut serta dalam penyelesaian konflik Irak dan Kuwait. PBB juga beranggapan bahwa apa yang dilakukan Irak merupakan suatu pelanggaran terhadap hak asasai manusia. Itulah sebabnya PBB mengecam tindakan Irak yang mencoba menguasai wilayah Kuwait.

Upaya PBB dalam menyelesaikan konflik Irak dan Kuwait dilakukan dengan mengeluarkan beberapa instruksi. Instruksi PBB dituangkan ke dalam resolusi yang dikeluarkannya. Resolusi konflik yang dikeluarkan PBB diantaranya yaitu berisi tentang perintah agar Irak segera menarik mundur pasukannya, sanksi ekonomi kepada Irak, melindungi warga negara asing dari dampak yang timbul akibat invasi Irak terhadap Kuwait, pembentukan komite sanksi khusus untuk memantau embargo oleh negaranegara anggota, pemberian hak kepada komite sanksi nasional, kerjasamanya dengan Amerika Serikat, dan lain sebagainya. Hal itu menunjukkan adanya keseriusan dari PBB dalam mengupayakan terciptanya penyelesain konflik Irak dan Kuwait.

\section{DAFTAR PUSTAKA}

Adolf, H. (2020). Hukum Penyelesaian Sengketa Nasional. Jakarta: Sinar Grafika.
Anggono, E. D. (2002). Upaya Irak dalam Menyelesaikan Krisis Teluk Melalui Imbalan Bersyarat/ Lingkaged (Studi Kasus Invasi Militer Irak terhadap Kuwait 1990-1991). Skripsi. Jember: Fakultas Ilmu Sosial dan Ilmu Politik.

Annisa, F.S.; Setiyono, J.; \& Supriyadhie. (2019). Kontribusi International Committee of The Red Cross (ICRC) dalam Perlindungan Tawanan Perang yang Mengalami Penyiksaan di Penjara Abu Ghraib. Diponegoro Law Journal. April 2019 hal 2 ISSN: 2527-4031

Cleveland, H. (1995). Lahirnya Sebuah Dunia Baru. Jakarta: Yayasan Obor Indonesia. Indriana, N. (2017). Pemetaan Konflik di Timur Tengah (Tinjauan Geografi Politik). An-Nas: Jurnal Humaniora Maret 2017 hal 18 ISSN: 2597-7822

Latifah, N.A \& Ghozali, M. (2019). Studi Empiris Tentang Perkembangan Sistem Ekonomi Syariah di Timur Tengah. Jurnal Masharif al-Syariah:Jurnal Ekonomi dan Perbankan Syariah November 2019 hal 75 ISSN: 25276344

Mariyati, A. (2003). Upaya Saddam Hussein Menghadapi Sanksi PBB Pasca Perang Teluk II. Skripsi. Jember: Fakultas Ilmu Sosial dan Ilmu Politik Universitas Jember.

Nazir, M. (1988). Metode Penelitian. Jakarta: Ghalia Indonesia.

Pusat Data dan Analisis Tempo. (2019). Konflik Irak - Kuwait - Amerika dalam Perang Teluk. Jakarta: Tempo Publishing

Sihbudi, M. R. (1997). Indonesia Timur Tengah: Masalah dan Prospek. Jakarta: Gema Insani Press.

Setyosari, P.,Widijoto, H. (2007). Metode Penelitian Pendidikan. Malang: Rosindo.

Solichien, Y. (2014). Saddam Hussein: Kisah di Balik Perang Teluk 1990-1991. Jakarta: PT Elex Komputindo. 
Winarno, B. (2014). Satu Dekade Pasca invasi AS di Irak. Jurnal Hubungan Internasional Oktober 2014 hal 122 ISSN: 2503-3883 